\title{
Temperature Distribution of Biodiesel Blends Combustion in Boiler using CFD-Fluent
}

\author{
Lia Cundari, Leily Nurul Komariah, Novia, Isni Maretha, Lia Septiana \\ \# Chemical Engineering Department, Sriwijaya University, Inderalaya Ogan Ilir, 30862, Indonesia \\ E-mail: icun_hyang02@yahoo.com,leilydiaz@yahoo.com
}

\begin{abstract}
The use of biodiesel have been tested on some combustion devices extensively, including on the boiler. Biodiesel blends use in boiler is possibly affected the behaviour of combustion. It can be evaluated by analysing the exhaust gas composition and temperature. This study is conducted to show the distribution of temperature in the combustion chamber and boiler stack's using Computational Fluid Dynamic (CFD) software Fluent. Experimentally, the tests carried out on the fire tube boiler vertical type cylinder with pressure of 3 bar. Temperature measurement is performed at three points in the combustion chamber and boilers' stack using optional thermocouple and gas analyser IMR 1400. The biodiesel used in the tests is palm oil based with blending portion varies from $5-25 \%$. The results show that in the higher blend of biodiesel, the temperature of combustion chamber tend to be lower but the exhaust gas temperature at the end of the chimney was likely to increase. On the other hand, the simulation using Fluent showed the pattern of temperature distribution was relatively equal between the use of biodiesel in the blends under $25 \%$ compared to the use of diesel (B0).
\end{abstract}

Keywords—biodiesel; boiler; combustion; CFD; temperature distribution

\section{INTRODUCTION}

Boiler is industrial equipment which is used for steam production. Steam can be used for heating agent or movement energy. The heat comes from combustion of fuel which is done in Boiler.

Depletion of world oil reserves and combustion effect of fossil fuel support the use of alternative energy. Biodiesel is one of alternative energy which is could be used for reduce depedence of fossil fuel.Compared with conventional diesel oil such as solar, biodiesel known as green energy, renewable, and have clean exhaust gas composition. Biodiesel and solar blend in varies portion can be used directly without machine modifications [1].

Complete combustion reaction produces $\mathrm{CO}_{2}$ and $\mathrm{H}_{2} \mathrm{O}$. Problem which is often encountered in boiler performance is incomplete combustion. To have a complete combustion, higly and uniform temperature of combustion chamber were needed. High temperature can be achieved from complete combustion, while uniform temperature depend on heat transfer in combustion chamber. This heat transfer will be affected temperature distribution in combustion chamber and boiler stack.

One of the effort that used to know temperature distribution, oxygen required and combustion products resulted such as $\mathrm{CO}_{2}$ and $\mathrm{H}_{2} \mathrm{O}$ is $\mathrm{CFD}$ (computational fluid dynamic). CFD is a fluid dynamic analysis in a system by using algorithm numeric method based on computer [2]. Reference [2] worked on gas combustion that resulted from biomass gasification in premixed gas burner by 3D computational fluid dynamic method. He found the increased air flow rate would be reduced temperature and shorted flame. This caused by the amount of air would be added excess air.

Syukran [3] described the utilization of CFD program to evaluate temperature distribution in combustion chamber of boiler $51 \mathrm{MW}$ by using MFO (medium fuel oil) and LNG (liquiefied natural gas). He reported the average temperature distribution in boiler relatively equal to maximum temperature of MFO and LNG from 1500 to $1700^{\circ} \mathrm{C}$. Small differences occured in outlet of boiler that caused by material flowrate differences, inlet MFO greater than LNG.

Studied performance of oil burner system utilizing various biodiesel blends [4]. They elaborated the enhancement of biodiesel in blends would be reduced temperature in large amount. Enhancement of biodiesel in blends declined calorific value of fuel.

Nayak and Pattanaik [5] also reported impact of biodiesel on combustion, performance and exhaust emissions of diesel engines. These author found machine that used B100 as fuel resulted small exhaust gas temperature compared to solar. This showed biodiesel have longer initial combustion and expantion mass. 
A review on combustion, performance, and emission characteristics of fuels derived from oil seed crops (biodiesels) was investigated by Gopinath et.al [6]. They analyzed biodiesel combustion characteristics almost similar to diesel. However, performance of biodiesel slightly lower than diesel. Biodiesel produced more nitrogen oxide, while carbon monoxide, hydrocarbon, and smoke emission in comparable value with diesel.

In this research we report temperature distribution in boiler which is used solar-biodiesel blends as fuel with $5 \%$, $10 \%, 20 \%$ and $25 \%$ biodiesel added.

\section{MATERIAL AND METHODS}

We simulate fire tube boiler with dimensions as follows :
a. Air channel : $4 \mathrm{~cm} \mathrm{x} 10 \mathrm{~cm}$
b. Fuel channel : $0.5 \mathrm{~cm} \times 20 \mathrm{~cm}$
c. Burner : $25 \mathrm{~cm}$ x $20 \mathrm{~cm}$
d. Flame tube : $30 \mathrm{~cm}$ x $100 \mathrm{~cm}$
e. Distance of tube to boiler base : $20 \mathrm{~cm}$
f. Fire tube : $10 \mathrm{~cm} \mathrm{x} 70 \mathrm{~cm}$
g. Initial stack : $20 \mathrm{~cm} \mathrm{x} 40 \mathrm{~cm}$
h. Middle stack : $20 \mathrm{~cm}$ x $70 \mathrm{~cm}$ (slope 30o)
i. Final stack : $20 \mathrm{~cm} \mathrm{x} 40 \mathrm{~cm}$

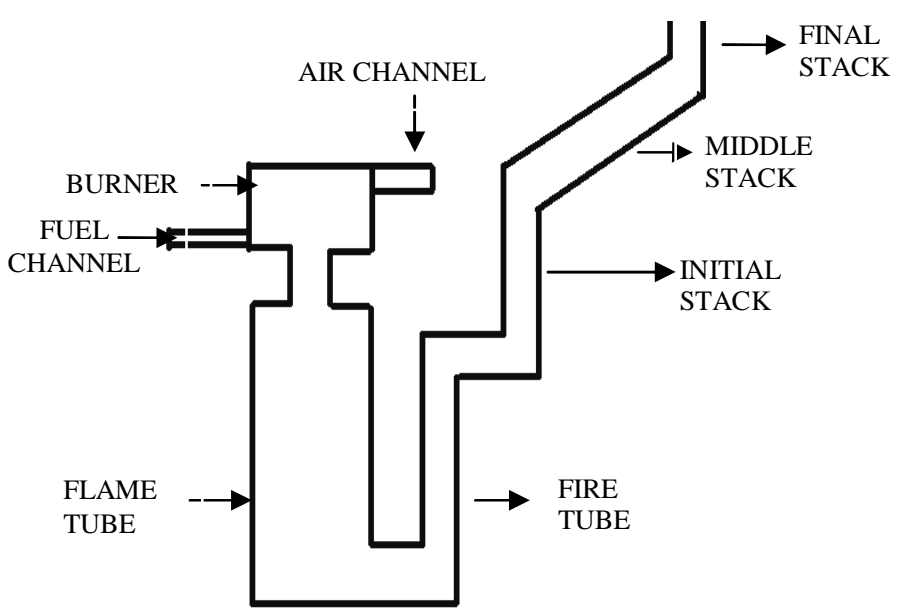

Fig. 1. Sketch of Boiler

This simulation is done by software Fluent. Model of completions are:
a. Steady state
b. Heat transfer
c. k- epsilon RNGturbulence
d. Speces transportorgas combustion
e. Reaction measurement by Eddy dissipation model

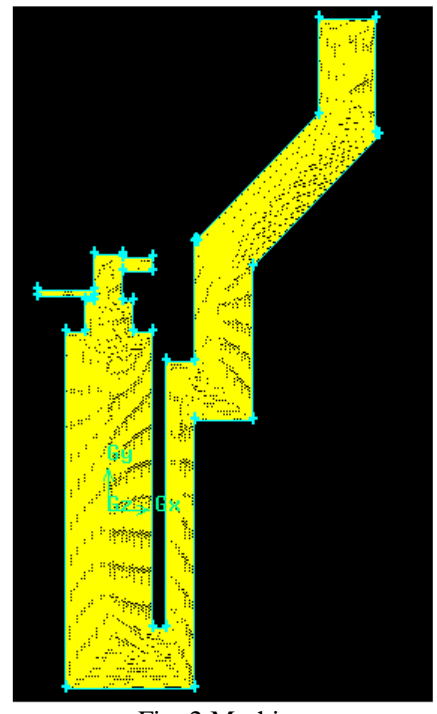

Fig. 2 Meshing

In this study numerical analysis are given by mass, momentum, and heat conservation equations as follows :

$$
\begin{aligned}
& \nabla(\rho V)=0 \\
& \rho\left[\frac{\partial \vec{V}}{\partial t}+(\vec{V} \cdot \nabla) \vec{V}\right]=-\Delta p+\mu \nabla^{2} \vec{V}+\rho \dot{f} \\
& \rho c_{p}\left[\frac{\partial T}{\partial t}+(\vec{V} \cdot \nabla) T\right]=k \nabla^{2} T+\emptyset
\end{aligned}
$$

With steady state assumption, $\partial / \partial \mathrm{t}$ at the equations will be eliminated. After modelling the process, boundary condition will be determined as follows :

a. Air injection velocity $0.05 \mathrm{~m} / \mathrm{s}$

b. Fuel velocity : B0 $0,003 \mathrm{~m} / \mathrm{s}$, B5 $0,0029 \mathrm{~m} / \mathrm{s}$, B 10 $0,0027 \mathrm{~m} / \mathrm{s}, \mathrm{B} 200,0023 \mathrm{~m} / \mathrm{s}$ dan B25 0,0018 m/s.

c. Exhaust gas temperature: B0 $382 \mathrm{~K}$, B5 $378 \mathrm{~K}, \mathrm{~B} 10$ $376 \mathrm{~K}, \mathrm{~B} 20360 \mathrm{~K}$ dan B25 $354 \mathrm{~K}$.

d. Fuel temperature $300 \mathrm{~K}$ and air temperature $303 \mathrm{~K}$.

\section{RESULTS AND DISCUSSION}

\section{A. Fuel Characteristics}

The purpose of enrich cement of fuel quality is to develop quality of combustion. One way to get that is using alternative fuel, such as biodiesel. Diesel oil has physical and chemical properties that can effect its combustion. One of the properties is heating value of $\mathrm{C}, \mathrm{H}, \mathrm{N}, \mathrm{O}$, and $\mathrm{S}$.

TABLE I

BIODIESEL AND SOLAR CHARACTERISTIS

\begin{tabular}{lcccccc}
\hline Parameter & Unit & B0 & B5 & B10 & B20 & B25 \\
\hline Carbon & $\%$ & 84,15 & 83.76 & 83.36 & 82.58 & 82.19 \\
Hidrogen & $\%$ & 12,67 & 12.62 & 12.58 & 12.49 & 12.44 \\
Nitrogen & $\%$ & 0,5 & 0,5 & 0.5 & 0.5 & 0.5 \\
Oxigen & $\%$ & 2,93 & 3.39 & 3.85 & 4.76 & 5.22 \\
Sulphur & $\%$ & 0,1 & 0,095 & 0.09 & 0.08 & 0.075 \\
Heating & MJ/lb & 46.8 & 46.467 & 46.133 & 45.467 & 45.135 \\
Value & & & & & & \\
\hline Report in [7]
\end{tabular}


Fuel analysis is used to determine pollutant emission, such as amount of carbon, sulphur, oxygen, and hydrogen in fuel that will be burned.

\section{B. Effect of Biodiesel Addition to Combustion Chamber and Stack Temperature}

Biodiesel is methyl ester or ethyl ester compound which is used as an alternative fuel for fossil fuelsubtitution. The advantages ofbiodiesel are comes from renewable source, clean combustion so it doesn't contribute carbon dioxide enrichment, and good for environment [8].

Combustion is a fast process or oxidation reaction between fuel and oxidator agent that caused flare and heat. To execute combustion, calorific value is needed to evaluate. Amount of calor required says as calorific value. Combustion reaction :

$$
\mathrm{C}_{\mathrm{x}} \mathrm{H}_{\mathrm{y}}+\mathrm{a} \mathrm{O}_{2} \longrightarrow \mathrm{CO}_{2}+\mathrm{c} \mathrm{H}_{2} \mathrm{O}
$$

Combustion is a mixing between fuel and air. Complete combustion is effected by turbulence of inlet air flow. If turbulence was increased, distorsion of fire absorption will be increased flare temperature [9].

TABLE II

TEMPERATURE MEASUREMENT

\begin{tabular}{ccccccc}
\hline Parameter & Unit & B0 & B5 & B10 & B20 & B25 \\
\hline$* \mathrm{~T}_{1}$ & $\mathrm{~K}$ & 800 & 788 & 778 & 773 & 700 \\
$* * \mathrm{~T}_{2}$ & $\mathrm{~K}$ & 593 & 588 & 583 & 573 & 498 \\
$* * * \mathrm{~T}_{3}$ & $\mathrm{~K}$ & 382 & 378 & 376 & 376 & 354 \\
Laju fuel & $\mathrm{m} / \mathrm{s}$ & 0.003 & 0.0027 & 0.0025 & 0.0022 & 0.018
\end{tabular}

$\begin{array}{ll}* \mathrm{~T}_{1} & =\text { Combustion Chambertemperature } \\ * * \mathrm{~T}_{2} & =\text { Initial stack gas }\end{array}$

$* * * \mathrm{~T}_{3} \quad=$ Final stack gas

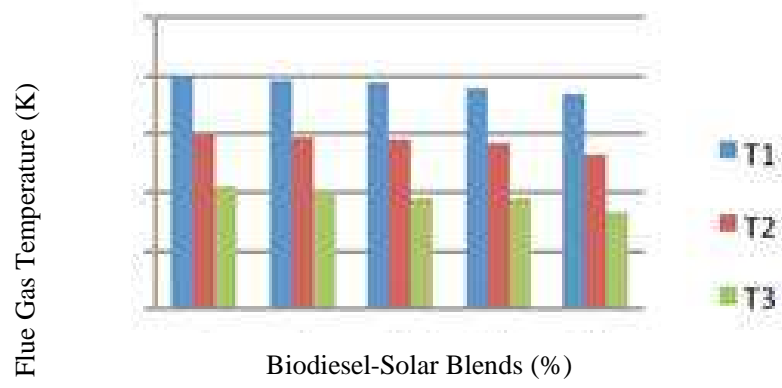

Fig. 3. Effect of Biodiesel Blends to Temperature Distribution

Figure 3 shows that increasing biodiesel added to the mix fuel will be decreased temperature from combustion chamber through stack gas. This occurs because of calorific value of fuel declined while biodiesel persentages increased [10]. Combustion needs calor to be existed, amount of calor required is defined as calorific value. Fuel calorific value is amount of complete combustion energy released per mass or volume fuel. This shows that fuel calorific value directly proportional to combustion temperature resulted.
In fire tube boiler, flame and hot gas are produced from fuel combustion. To transfer the heat induced, hot gas is passed through tubes outsite firewall which is surrounded by water or steam. Amount of heat absorption shows in figure 4 .

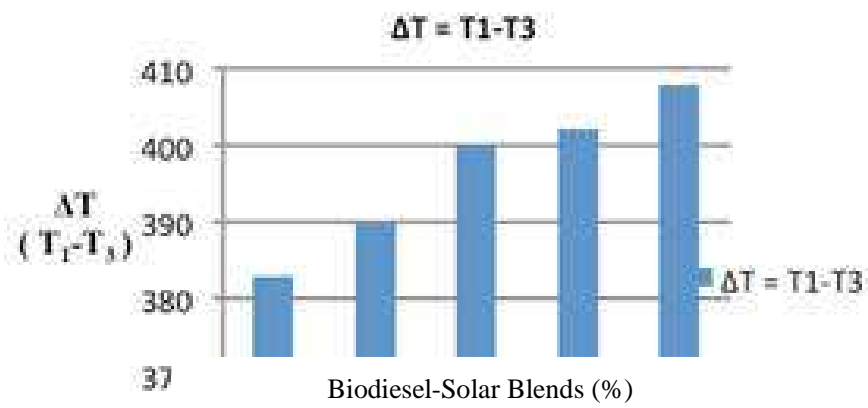

Fig. 4 Heat absorption

Commonly heat transfer in the boiler occurs through radiation, convection, and conduction. Radiation appears between flame and firewall. Radiation energy depends on number of surface heat absorption that exposure by flare. In convection, heat transfer occurs between flue gas and firewall. Finally, in conduction, heat transfer exist through firewall to the air [3].
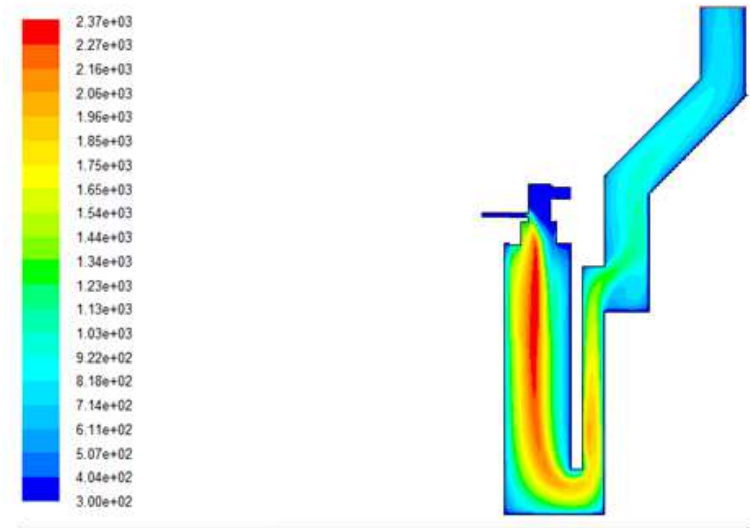

Contours of Static Temperature (k)

Fig. 5 Temperatur Distribution Contour $\left({ }^{\circ} \mathrm{K}\right) \mathrm{B} 0$ (Solar)
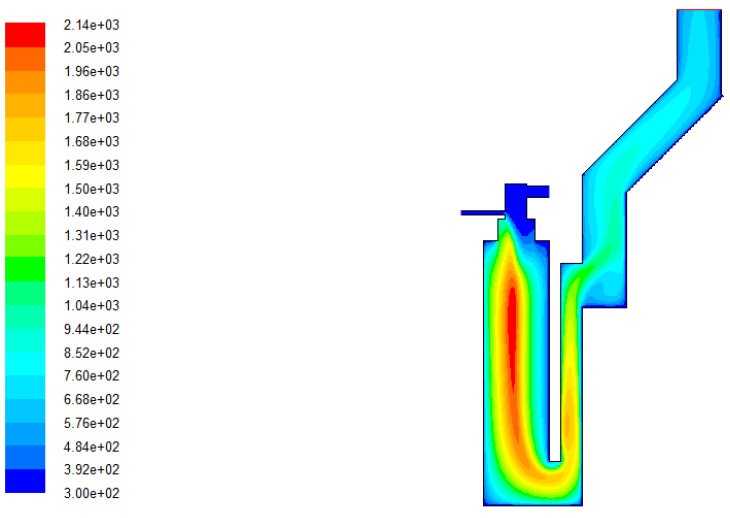

Contours of Static Temperature (k)

Fig. 6 Temperatur Distribution Contour $\left({ }^{\circ} \mathrm{K}\right) \mathrm{B} 5$ 


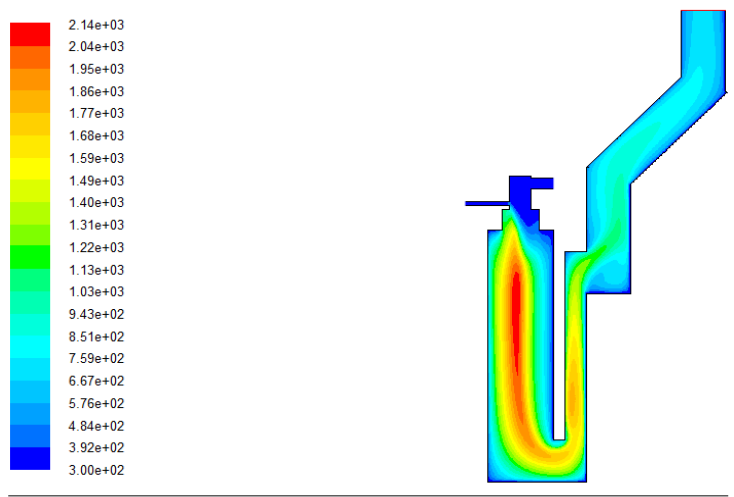

Zontours of Static Temperature (k)

Fig.7 Temperatur Distribution Contour $\left({ }^{\circ} \mathrm{K}\right) \mathrm{B} 10$

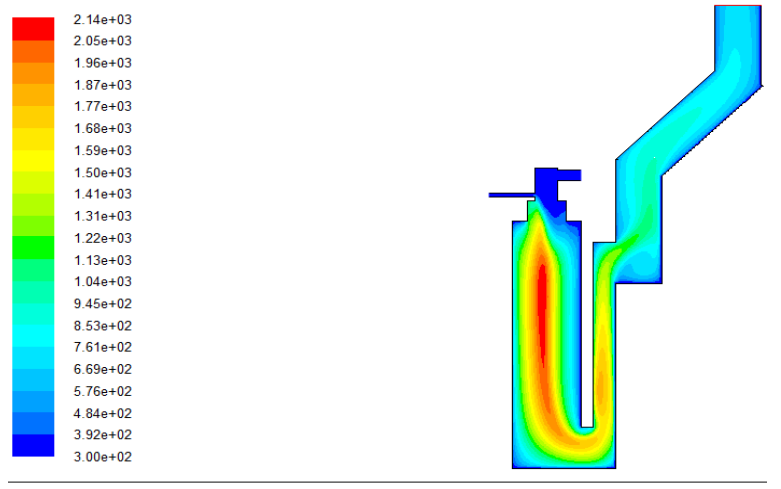

Zontours of Static Temperature (k)

Fig.8 Temperatur Distribution Contour $\left({ }^{\circ} \mathrm{K}\right) \mathrm{B} 20$

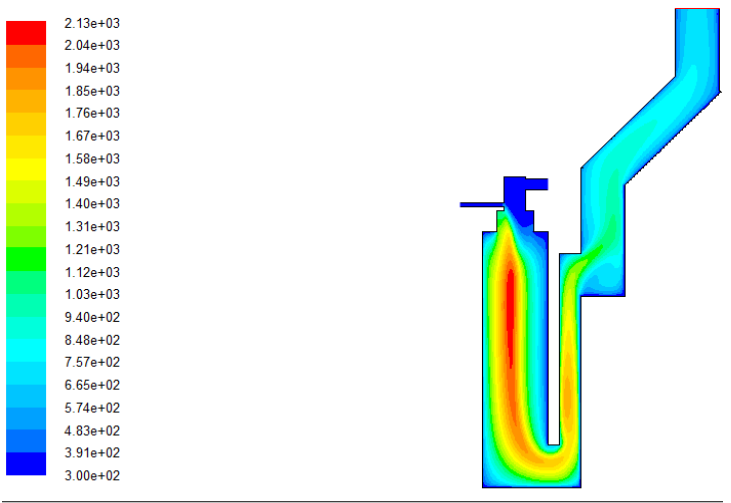

Sontours of Static Temperature (k)

Fig. 9 Temperatur Distribution Contour $\left({ }^{\circ} \mathrm{K}\right) \mathrm{B} 25$

The highest temperature occurs in inlet of combustion chamber. Fire starting to grow in this burner zone, because of fuel-oxygen mixing. After that, temperature decreases through fire tube to final stack of boiler. This is caused by fire tube wall heat absorption, so that heat will be absorbed by fluid (water).

In flame tube area, flue gaswith high temperature from $2370{ }^{\circ} \mathrm{K}$ to $2130{ }^{\circ} \mathrm{K}$ tends to reach the wall. This is caused by burner construction as inlet for fuel and air.Type of burner used is Monarch Oil Burner 1-3. At modelling, suitability between actual burner construction and model is very difficult to get. So, pattern of distribution temperature through burner will be effected.
Flue gas temperature profile through flame tube tends to deplete. This is caused by transfer firewall heat absorption to fluid. For solar, temperature reduces from $2370{ }^{\circ} \mathrm{K}$ to 611 $1340{ }^{\circ} \mathrm{K}$. However for bodiesel, temperature reduces from $2140-2130{ }^{\circ} \mathrm{K}$ to $576-131{ }^{\circ} \mathrm{K}$.

Simulation doesn't show the form of fire, but describes distribution temperature which is occured as combustion effect. In temperature contours, maximum temperature is relatively equal. Only small differences will be visible between them.

One of factors that effect temperature is ratio of fuel-air for combustion, while ratio of solar-biodiesel blends (BXX) doesn't effect to temperature distribution. BXX define as mix of biodiesel and solar, such as B20 which is consist of $20 \%$ biodiesel and $80 \%$ solar.

Higher biodiesel percentage will be increased viscosity. Viscosity of each blends has differences, so that in this research fuel velocity is made in varies. Besides that fuel doesn't preheat so fuel velocity is determined by viscosity value

\section{CONCLUSIONS}

There is no significant temperature change in combustion between B5, B10, B20, B25 and B0 (Solar). It means biodiesel addition doesn't affect temperature profile, so the highest portion of biodiesel (25\%) can be used for boiler fuel.

\section{REFERENCES}

[1] Harvendi, A., "Kaji Eksperimental Perbandingan Prestasi Dan Emisi Gas Buang Motor Bakar Campuran Solar dengan Biodiesel, CPO, Minnyak Jarak Dan Minyak Kelapa”, Jurnal Teknika No. 29 Vol.1 Tahun. XV, 2008.

[2] Surjasatyo, Adi, "Pembakaran Gas Hasil Gasifikasi Biomassa di Premixed Gas Burner dengan Metode 3D Computational Fluid Dynamic", Departemen Teknik Mesin, Fakultas Teknik, Universitas Indonesia, Jakarta, 2010.

[3] Syukran, "Pemanfaatan Paket Pemograman CFD Untuk Mengkaji Distribusi Temperatur Ruang Bakar Boiler 51 MW Berbahan Bakar MFO dan LNG", Program Studi Teknik Mesin Politeknik Negeri Lhokseumawe, Lhokseumawe, 2011.

[4] Hanafi, M., Nazri, M., "Performance of Oil Burner System Utilizing various Palm Biodiesel Blends", International Journal of Mechanical and Materials Engineering, Volume 6, Issue number 3, page 273-278, 2009.

[5] Nayak, S.W., Pattanaik, W.B., "Experimental Investigation on Performance and Emmssion Charactheristics of Diesel Engine Fuelled with Mahua Biodiesel Using Additive", 4th International Conference on Advances in Energy Research 2013 (ICAER ), Energy Prodia, page 569-579, 2014.

[6] Gopinath, A., et.al., "A review on Combustion, Performance, and Emission Characteristics of Fuel Derived from oil Seed Crops (Biodiesel)", Australian Journal of Crop Science, Volume 7, Issue 9, page 1350-1354, 2013.

[7] Komariah, et.al.,"Emission factors of biodiesel combustion in industrial boiler: A comparison to fossil fuel", Journal of Renewable and Sustainable Energy 5, 2005.

[8] Nagi, J., et.al., "Palm Biodiesel an Alternative Green Renewable Energy for the Energy Demands of the Future", International Conference on Construction and Building Technology (ICCBT), page 79-94, 2008

[9] Haque, et.al.,"Free Surface Turbulent Flow Induced By A Rashton Turbine in an Unbaffled Dish-Bottom Stirred Tank Reactor : LDV Measurements and CFD Simulations", The Canadian Journal of Chemical Engineering Vol. 89, 2011.

[10] Mantari, Muhammad., Jaafar, Muhammad.,"Performance Of Oil Burner System Utilizing Various Palm Biodiesel Blends", Department of Aeronautical Engineering, Faculty of Mechanical Engineering, UniversitiTeknologi Malaysia, 81310 UTM Skudai, Johor, Malaysia, 2009. 